\title{
Thoughts on Talent Gathering under the Background of Ecological Protection and High Quality Development in the Yellow River Basin
}

\author{
Xiaojing Liu \\ Anyang Normal University, Anyang, China \\ Email: liuxiaojing2000_@126.com
}

How to cite this paper: Liu, X. J. (2021). Thoughts on Talent Gathering under the Background of Ecological Protection and High Quality Development in the Yellow River Basin. Open Journal of Social Sciences, 9, 378-387.

https://doi.org/10.4236/jss.2021.91028

Received: December 3, 2020

Accepted: January 25, 2021

Published: January 28, 2021

Copyright (อ 2021 by author(s) and Scientific Research Publishing Inc. This work is licensed under the Creative Commons Attribution International License (CC BY 4.0).

http://creativecommons.org/licenses/by/4.0/ (c) (i) Open Access

\begin{abstract}
To promote the high-quality development of Anyang City, Henan Province, talent is the core driving force of innovation, and talent gathering can play a role of $1+1>2$. By using the methods of literature research and comparative study, this paper analyzes the current situation and difficulties of Talent Gathering in Anyang, Henan Province under the background of ecological protection and high-quality development of the Yellow River Basin. The results show that the current situation of Talent Gathering in Anyang needs to enhance the talent gathering effect from the aspects of industrial transformation, investment in scientific and technological innovation, regional development orientation, talent training mode, talent evaluation system, etc.
\end{abstract}

\section{Keywords}

High Quality Development, Talent Gathering, Regional Positioning,

Talent Evaluation

\section{Preface}

On September 18, 2019, when inspecting the Yellow River, General Secretary Xi (2019) pointed out: "ecological protection and high-quality development of the Yellow River Basin are major national strategies". Talent is the key to implement the national strategy of ecological protection and high quality development in the Yellow River Basin. Talent is the carrier of knowledge, technology and experience, and talent gathering can play a role of $1+1>2$, which makes the role of talent in regional development more important. To promote the 
high-quality development of Anyang City, Henan Province, to achieve the "one return, six major" objectives and tasks, and to accelerate the construction of a strong regional central city in the new era, we cannot do without the strong support of talents. Talent is the core driving force of innovation. Focusing on promoting ecological protection and high-quality development of the Yellow River Basin, Anyang, Henan Province, is building a strong regional city in the new era. It adheres to the high-quality development of the manufacturing industry as the main direction, takes the supply side structural reform as the main line, pays close attention to the transformation of traditional industries and the cultivation of emerging industries, deepens the reform of talent development system and mechanism, and improves the talent gathering effect.

\section{Literature Review}

Scholars at home and abroad focus on the phenomenon, motivation, carrier and effect of talent aggregation. Zhu (2002) studied the phenomenon of Talent Gathering earlier, and thought that talent gathering is a special behavior in the process of talent flow, which refers to the process that talents flow from different regions (or enterprises) to a specific region (or enterprise) due to the joint action of interests, spirit and environment. Zhang Chunhai and Sun Jian (2011) proposed that the speed and quality of talent gathering will be affected by the level of economic development, education level, investment in scientific research funds, income level and living environment. Zhao et al. (2019) conducted an empirical study on the impact of industrial agglomeration and its interaction on regional innovation capability.

There are many researches on ecological protection and high quality development of the Yellow River Basin in recent years. Zhang (2020) believed that ecological protection and high-quality development in the Yellow River Basin should be based on the people's sharing of development achievements, including basic public services such as education, employment, medical care, health care, social security, etc., and pay attention to the integrity and systematicness, the coordination and sustainable development of society, man and nature. Shi (2020) proposed that the supply side structural reform must be promoted to promote the high-quality development of the Yellow River Basin. Xie (2020) thinks that it is necessary to further improve the joint prevention and control mechanism and regional cooperation mechanism of water ecological environment. Zhao (2020) proposed the construction of GIS compound talents training mode. Liu (2020) believed that the talent training strategy should adapt to the new needs of national strategy, meet the new requirements of modernization, and integrate into the Yellow River culture. Zheng (2020) thinks that in the legislative practice, there are still some problems, such as the lack of comprehensive law in the Yellow River Basin, the overall quality of local legislation is not high, and the overall legislative thinking is not strong. Therefore, we should comprehensively improve the quality and level of the Yellow River legislation. 


\section{Research Object, Research Method and Conclusion}

Based on the basic population data of Anyang City, this study adopts the methods of literature research, comparative analysis, and the principle of combining quantitative analysis and qualitative analysis to analyze and process the information published publicly on the websites of Henan Provincial Bureau of statistics and Anyang Bureau of statistics, so as to understand the current situation and problems of talent concentration in Anyang City, It mainly includes the total amount of talents, category, level, talent policy status and other information.

\subsection{Research Object: Represented by Non-Public Ownership}

In the first half of 2020, the GDP of Anyang is 103.96 billion yuan, ranking the $12^{\text {th }}$ and $16^{\text {th }}$ in growth rate of the whole province. In 2019, the total population of the city is 5.9479 million, and the permanent resident population is 5.192 million. According to the statistics of relevant departments, in 2019, more than 10,000 people were moved in and out of the city, with a net outflow of more than 10,000 , indicating that Anyang City is a city with a net population outflow.

In 2017, a total of 639 sample units of non-public enterprises were selected, including 388 Enterprises above the scale and 251 enterprises under the scale, and the sampling calculation was carried out according to the samples. In 2018 and 2019, 88 non-public enterprises were selected: 4 in mining industry, accounting for 4.5\%; 73 in manufacturing industry, accounting for 83\%; 2 in power and gas supply industry, accounting for $2.3 \%$; 2 in wholesale and retail industry, accounting for $2.3 \%$; 3 in information transmission, software and information technology service industry, accounting for 3.4\%; one in scenic spot management, engineering technology design service and entertainment industry. In terms of the number of employees, there are 13 enterprises with more than 1000 employees, accounting for $14.8 \%$; 31 Enterprises with 300 - 1000 employees, accounting for $35.2 \%$; and 40 enterprises with 300 or less employees, accounting for $45.5 \%$.

This paper compares the status of human resources in 2017 and 2019, focusing on the analysis of the proportion of talent categories, focusing on the total category, education background and level.

\subsection{Results}

\subsubsection{Analysis of the Total Number of Talent Categories}

The sample survey shows that the total number of non-public talents in the city was 268,774 by the end of 2017. Among them, there are 96,226 management talents, accounting for $35.8 \%$ of the total talents; 124,994 professional and technical talents, accounting for $46.5 \%$ of the total; and 59,736 high skilled talents, accounting for $22.2 \%$ of the total. In 2019, there are 5256 management personnel, accounting for $39.4 \%$ of the total talent; 5067 are professional and technical personnel, accounting for $38 \%$ of the total talent; and 3011 are highly skilled personnel, accounting for $22.6 \%$ of the total talent. 


\subsubsection{Talent Level Analysis}

In 2017, there were 51,018 middle and senior management talents, accounting for $53 \%$ of the total management talents, accounting for $19 \%$ of the total talents, increased by $15.4 \%$ and $2.8 \%$ respectively compared with 2016 ; there were 49,795 intermediate, deputy senior and senior professional and technical talents, accounting for $39.8 \%$ of the total professional and technical talents, accounting for $18.5 \%$ of the total talents; 59,736 high skilled talents, accounting for $22.2 \%$ of the total talents, with a year-on-year increase of 3.3\%. The data shows that the number of high-tech and high skilled talents is increasing, and the talent composition is gradually optimized. However, the proportion of these high-tech and high skilled talents is still low, accounting for $59.7 \%$ of the total, and junior technical and skilled personnel are still the main force of non-public talents.

In 2019, there are 2161 middle and senior management personnel, accounting for $41.1 \%$ of the total number of management personnel, accounting for $16.2 \%$ of the total talent; 2068 are intermediate, deputy senior and senior professional and technical personnel, accounting for $40.8 \%$ of the professional and technical personnel, accounting for $15.5 \%$ of the total talent; there are 3011 highly skilled personnel (senior technicians, technicians, senior workers), accounting for $9.4 \%$ of the skilled personnel, accounting for $22.6 \%$ of the total talent. This shows that there is a serious shortage of highly skilled personnel who have rich experience, can skillfully use various specialized skills and have practical operation skills and skills (Figure 1).

\subsubsection{Talent Education Analysis}

From the perspective of educational background, in 2017, there were 4666 people with graduate degree or above, accounting for $1.7 \%$ of the total talent; 46,114 people with bachelor's degree, accounting for $17.2 \%$ of the total talent; 86,946 people with college degree, accounting for $32.3 \%$ of the total talent; 131,048 people with secondary school degree or below, accounting for $48.8 \%$ of the total talent; nearly half of the non-public talents are low educated or skilled

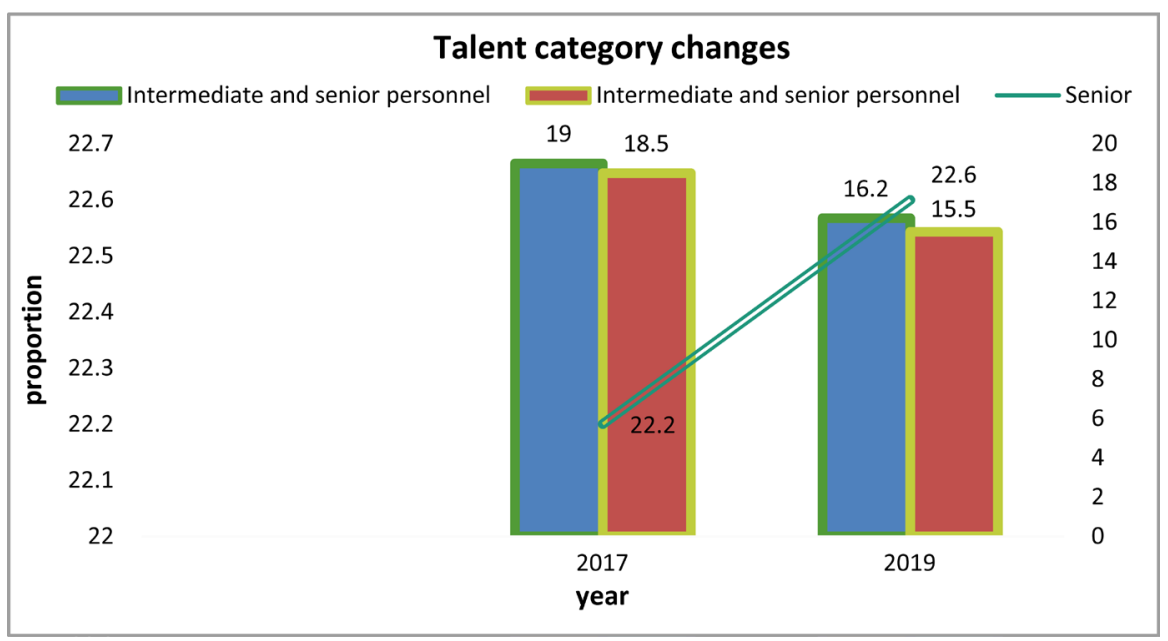

Figure 1. Comparison of 2017 and 2019 talent categories. 
personnel, and the proportion of highly educated personnel in non-public talents is still low.

The data shows that, with a slight decline in the total number of talents, the number of talents with a graduate degree or above shows a rapid growth trend, which is gratifying. However, the total amount is small, accounting for only $1.7 \%$ of the total talents, while the number of talents with bachelor's degree decreases more, which shows that high-quality talents in non-public enterprises are losing, and the education structure still needs to be optimized.

In 2019 , there are 385 graduate students and above, accounting for $2.9 \%$ of the total talent; 2109 people with bachelor's degree, accounting for $15.8 \%$ of the total talent; 3573 people with college degree, accounting for $26.8 \%$ of the total talent; and 7267 people with secondary school education or below, accounting for $54.5 \%$ of the total talent. The number of people with college degree or above has increased steadily, while the number of people with graduate degree or above is growing rapidly.

The survey results show that the talent structure of non-public sectors in Anyang in 2017 and 2019 is unreasonable, and the overall cultural level is low. There are many junior staff, and there is a shortage of professional and technical talents and high skilled talents. There are few compound talents with high education background who can understand the specialty and management (Figure 2).

\subsubsection{Analysis on the Current Situation of Talent Gathering}

Considering the actual situation, Anyang City, Henan Province, focuses on promoting the ecological protection and high-quality development of the Yellow River Basin, builds a strong regional central city in the new era, adheres to the high-quality development of the manufacturing industry as the main direction, takes the supply side structural reform as the main line, pays close attention to the transformation of traditional industries and the cultivation of emerging industries, and deepens the reform of talent development system and mechanism. Around the construction of a strong regional central city in the new era, Anyang specially plans to cultivate four 100 billion level industries of "new energy vehicles

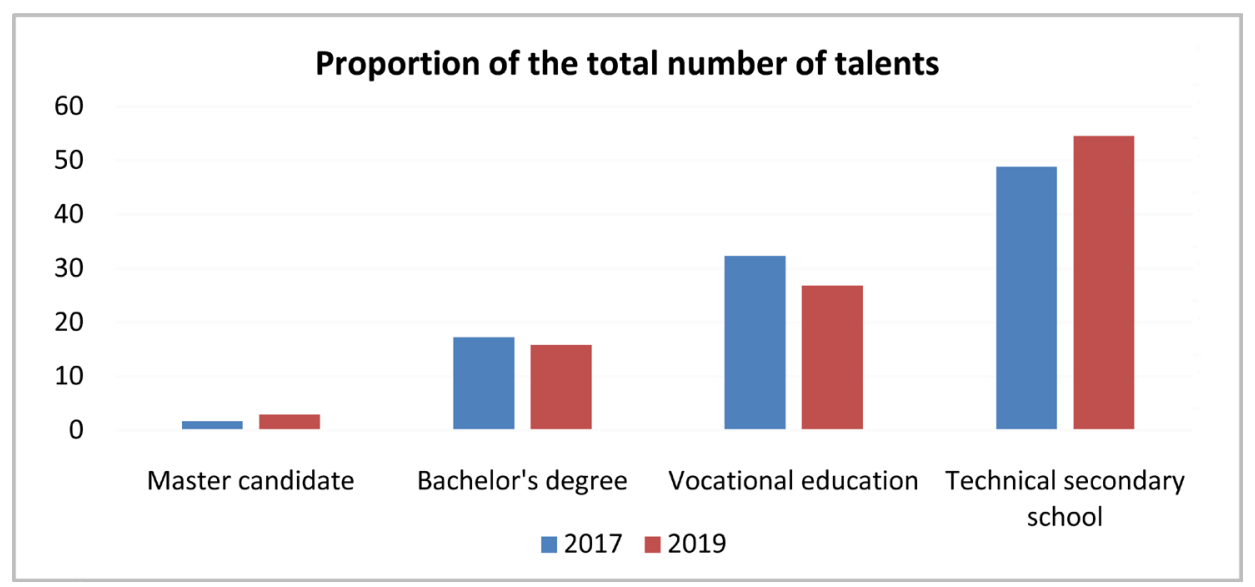

Figure 2. Proportion of the total number of talents. 
and parts, high-end equipment manufacturing, high-quality steel and deep processing, and cultural tourism". By 2025, it plans to achieve the main business income of more than 500 billion yuan, which requires about 600,000 technical personnel, management personnel and skilled personnel, at present, there are less than 300,000 talents in Anyang, which is more than half of the gap. Therefore, many measures should be taken to attract and retain talents (Table 1).

On March 24, 2020, Anyang City launched the "Huanquan gushing" talent gathering plan. From the city's key enterprises, the first batch of 1001 enterprises were selected, and a number of key and important posts were taken out to open arms to all kinds of talents. At the same time, a package of preferential policies has been issued in terms of settlement policy, housing subsidies, living subsidies, innovation and entrepreneurship subsidies, family placement, education and enrollment. Among these 1001 key enterprises, there are 98 enterprises of nonpublic economy type, accounting for $9.8 \%$. Therefore, this talent gathering plan will definitely promote the development of talents in non-public sectors and improve the quality of talents in non-public sectors. Since April 2020, 374 urgently needed professional and technical personnel have been introduced, 546 signed contracts, and 4071 people have been recruited for examination. As of October 24-25, Anyang City, Henan Province, participated in the third "China Henan talent recruitment innovation and Development Conference" and reached the signing intention of 1332 people (Table 2).

Table 1. Summary of talent policy documents.

\begin{tabular}{|c|c|}
\hline Year & File Name \\
\hline 2018 & $\begin{array}{l}\text { Implementation Opinions on Deepening The Reform of Talent Development System and } \\
\text { Mechanism and Accelerating the Construction of Talent City }\end{array}$ \\
\hline \multirow[t]{4}{*}{2019} & $\begin{array}{l}\text { Implementation Opinions on Implementing the Whole Chain of "Great Talent Concept" } \\
\text { to Promote The Development of Talents }\end{array}$ \\
\hline & $\begin{array}{l}\text { Division of Tasks for Formulating Supporting Policies on Deepening the Reform of Talent } \\
\text { Development System and Mechanism }\end{array}$ \\
\hline & $\begin{array}{l}\text { Notice on Further Implementing The Decision-making Power of Public Institutions' } \\
\text { Employees during the Second Henan Innovation And Development Conference }\end{array}$ \\
\hline & $\begin{array}{l}\text { Measures of Anyang City of Henan Province for The Identification and Support of } \\
\text { High-level Talents }\end{array}$ \\
\hline 2020 & $\begin{array}{l}\text { "Opinions of Anyang City, Henan Province on The Implementation of" Huan Quan } \\
\text { Yongliu "Talent Gathering Plan to Accelerate the Construction of A Strong City as a } \\
\text { Regional Center in the New Era" }\end{array}$ \\
\hline
\end{tabular}

Table 2. Preferential policy for talents.

\begin{tabular}{cl}
\hline Talent category & \multicolumn{1}{c}{ The specific explanation } \\
\hline Talents in short supply & $\begin{array}{l}\text { Talents of key projects, key enterprises, key industries and } 1001 \text { key } \\
\text { enterprises in "four hundred billion level" industries }\end{array}$ \\
Youth reserve & Anyang settled in the initial entrepreneurial talent \\
Other special talents & Other recognized talents \\
\hline
\end{tabular}


However, we must clearly realize that under the background of implementing the national strategy of ecological protection and high-quality development in the Yellow River Basin, there are still some difficulties in talent gathering, which need to be solved urgently. The high-quality development of the Yellow River Basin, from the main contradiction, is how to achieve high-quality development under the constraints of resources and environment. At present, the development of modern industries in the Yellow River Basin, such as high-tech industries and strategic emerging industries, is still lagging behind, facing the problem of ineffective transformation of new and old kinetic energy and severe challenges of industrial structure fault risk.

\subsubsection{Bottleneck of Talent Gathering}

The survey results show that the talent structure of non-public sectors in Anyang in 2017 and 2019 is unreasonable, and the overall cultural level is low. There are many junior staff, and there is a shortage of professional and technical talents and high skilled talents. There are few compound talents with high education background who can understand the specialty and management.

At the same time, there is still a big gap in the number of talents, however, compared with the talent demand of national central city construction, there is still a long way to go. At present, all parts of the country are planting parasol trees to attract Phoenix. The major central cities have repeatedly made new moves in scrambling for high-level talents, and have issued various preferential policies to help urban development and bring external pressure to talent gathering in Anyang.

The regional distribution of talents is not balanced, and the aggregation effect of talents leads to the flow of financial and human resources to more developed areas, and high-end talents are concentrated in the urban areas, which can not radiate and cover the backward areas. According to the latest data of Anyang Municipal Bureau of statistics, $40.2 \%$ of the non private sector employees in urban areas were distributed in the urban areas in 2018. Most of the talents with higher quality are concentrated in the system and have poor mobility. Anyang City does not belong to the economically developed areas. The economic development of some counties and districts is general, and the existing talent education level, labor quality and ideological cognition are still relatively backward. It is difficult to retain high-end talents, which leads to the shortage of talents and the uneven distribution of talents in the urban area.

\section{Countermeasures}

\subsection{Promote Industrial Transformation and Strengthen the Carrier Function of Agglomeration}

We should give full play to the advantages of science and technology and talents of urban agglomerations and central cities, focus on competitive traditional industries and emerging industries with development potential, gather and integrate all kinds of innovation elements with the support of system and mechan- 
ism innovation, focus on scientific and technological innovation, attract national high-end elements and innovation elements, and strengthen regional division and cooperation among industries and industrial chains. We will promote the agglomeration, cluster and intensive development of characteristic and advantageous industries, and promote technology transfer and transformation. The key technologies that restrict industrial development should be solved to boost project cooperation and promote the transformation and development of related industries. Strive to attract more talents to enter and stay in Anyang City, Henan Province, so as to inject new vitality into the high-quality development of Anyang City in Henan Province.

\subsection{Increase Investment in Scientific and Technological Innovation and Strengthen the Advantages of Innovation and Development}

By 2021, the total social R \& D investment in Anyang City of Henan Province will account for more than $2.5 \%$ of GDP, and the proportion of financial science and technology expenditure in public budget expenditure will reach $3.0 \%$. In 2018, the national R \& D investment accounted for $2.19 \%$, with Beijing, Shanghai, Tianjin and Chongqing reaching $6.17 \%, 4.16 \%, 2.62 \%$ and $2.01 \%$ respectively, which is far behind the national average level and even greater than that of advanced provinces and cities.

\subsection{Define the Regional Development Orientation and Reform the Local Talent Training Mode on the Supply Side}

In the confrontation between the third and fourth tier cities and the developed cities, their attraction to talents is quite limited. They should not only face the competition of unified level cities, but also face the pressure of strong regional advantages and mature industries in the province. Give full play to the guiding role of the market to talents. Clear regional development orientation, implement dislocation competition strategy, and accurately introduce talents. In order to improve the efficiency of talent gathering, we should improve the talent echelon training support system and continuously enhance the competitiveness of talents. We should continue to optimize the talent development environment and stimulate the innovation and creativity of talents.

We should change the path dependence of blindly relying on introduction, avoid falling into the vicious cycle of "talent introduction brain drain talent re introduction", turn to high-intensity and fast-paced training of local innovation and entrepreneurship talents, enhance the ability of independent training of talents, realize the quality and quantity of self-cultivation talents, and inject new vitality into the high-quality development of Anyang City, Henan Province.

\subsection{Relying on University Resources to Cultivate High-Level Talents}

Relying on the resources of colleges and universities, enterprises, universities and scientific research institutes can jointly cultivate high skilled talents and voca- 
tional and technical talents. Set up a committee with entrepreneurs and industry experts as the main body to promote the joint construction of research centers by universities, research institutes and enterprises, "move enterprises into research institutes and build research institutes in enterprises", promote the deep integration of enterprises, universities and research institutes, and rapidly realize the matching of high-level talents with the market.

\subsection{Improve the Talent Evaluation System and Implement the Differential Evaluation System}

Reform the traditional talent evaluation, assessment, incentive mechanism and high-level talent introduction methods, and attract Compound Innovation and entrepreneurship teams and leading talents with international influence to join the high-quality development of the Yellow River Basin. Implement a differentiated talent evaluation system, combine "soft" and "hard" indicators, emphasize that basic research talents are mainly peer-reviewed, pay attention to the originality of achievements, scientific value and social impact, ensure basic and major innovative research, allow failure, tolerate treatment, and give enough time for team building. Applied research and planning development talents should highlight the market mechanism and increase the weight of patent invention and achievement transformation.

Construct different types of preferential policies for talent evaluation. We should open up special evaluation channels that are inclined to young talents, those in hard and remote areas and at the grass-roots level, talents from industrial and business circles, and high-level talents with major development strategies. For example, for young talents, we can relax the age limit and qualification color appropriately, and pay attention to the conditions of real talent, outstanding potential and being able to undertake important tasks.

\subsection{Establish a Sharing Mechanism and Adopt Flexible Policies}

We should encourage the exploration of cooperation between neighboring regions to build parks, strengthen the division of labor and cooperation between industries and different links of the industrial chain, support the development of industries with different characteristics in different regions, and avoid homogeneous competition. We should coordinate resources, deepen integration, and promote the development of science and technology resources from the state of separation, separation and segmentation to aggregation, aggregation and fusion. We should use the online and offline data integration capabilities of "information platform, market-oriented platform, mobile Internet platform" and other online and offline data integration capabilities and innovation industry service system to "pry" the talent gathering effect lever, and break through the bottleneck of innovation driven development, Flexible introduction of intelligence can reduce the cost of introduction, such as flexible temporary post, scientific and technological consultation, regular service, technology development and other 
means to explore "Enclave mode" and explore collaborative innovation platform. We will continue to strengthen the task of ecological environment protection and pollution prevention and control.

\section{Fund}

Soft Science Research Program of Henan Province (2018); Research on the Linkage Development between Zhengzhou and the Surrounding Towns from the Perspective of National Central City (No. 182400410577).

\section{Conflicts of Interest}

The author declares no conflicts of interest regarding the publication of this paper.

\section{References}

Anyang Launched "Huanquan Gushing” Talent Gathering Plan_Guangming Net. http://difang.gmw.cn/ha/2020-03/25/content 33683988.htm.2020.3.25

Liu, W. K. (2020). Analysis of Talent Training Strategy under the National Strategy of Ecological Protection and High Quality Development in the Yellow River Basin. China Water Conservancy, No. 11, 60-62 + 54 .

Shi, B. H. (2020). Era Connotation and Realization Path of High Quality Development in the Yellow River Basin. Theoretical Perspective, No. 9, 61-66.

Xi, J. P. (2019). Speech at the Symposium on Ecological Protection and High Quality Development of the Yellow River Basin-Xinhua.

http://www.xinhuanet.com/politics/leaders/2019-10/15/c 1125107042.htm.2019.10.18

Xie, H. Y. (2020). Discussion on the System and Mechanism of Ecological Protection and High Quality Development in the Yellow River Basin. China Economic and Trade Guide (Middle), No. 11, 122-123.

Zhang, G. S. (2020). Ecological Protection and High Quality Development in the Yellow River Basin: Connotation and Path. Journal of Harbin Institute of Technology (Social Science Edition), 22, 119-128.

Zhao, F. (2020). Research on GIS Compound Talents Training Mode Serving Ecological Protection and High Quality Development Strategy of the Yellow River Basin. Journal of Higher Education, No. 19, 7-11.

Zhao, Q. X., Xia, C. X., Shi, J. J. et al. (2019). Scientific and Technological Talent Agglomeration, Industrial Agglomeration and Regional Innovation Capability: An Empirical Analysis Based on Beijing Tianjin Hebei, Yangtze River Delta and Pearl River Delta. Science and Technology Management Research. 24 April 2019.

Zheng, S. G. (2020). Study on the Legislative Practice of Ecological Protection and High Quality Development in the Yellow River Basin-From the Perspective of Henan Province. Journal of Shanxi Institute of Political Science and Law Management, 33, 27-29+ 105.

Zhu, X. Z. (2002). On the Research of Talent Agglomeration. Business Research, No. 8. 